\title{
PROGRAM PENGEMBANGAN KEWIRAUSAHAAN DI FAKULTAS EKONOMI UNIVERSITAS NEGERI MANADO
}

\author{
Grace Jenny Soputan1), Nova Ch. Mamuaja2), Juliana Ohy³), \\ Made Krisnanda ${ }^{4)}$ \\ 1,23) Fakultas Ekonomi, Universitas Negeri Manado, Jl. Kampus Unima, Tondano, 95618, \\ Indonesia \\ 4)Fakultas Teknik, Universitas Negeri Manado, Jl. Kampus Unima, Tondano, 95618, Indonesia
}

Email: gracesoputan@unima.ac.id

\begin{abstract}
Abstrak
Trend setiap tahun lulusan pendidikan tinggi minat untuk berwirausaha relatif rendah. Hal ini dapat dilihat dari semakin banyak lulusan yang mendaftar menjadi Pegawai Negeri Sipil. Salah satu solusi untuk mengantisipasi hal tersebut adalah melatih mahasiswa untuk menjadi wirausaha mandiri pemula. Program Pengembangan Kewirausahaan (PPK) merupakan salah satu kegiatan pengabdian kepada masyarakat khusus untuk mahasiswa yang didanai oleh Kementerian Riset Teknologi dan Pendidikan Tinggi tahun 2019. Tujuan kegiatan ini adalah untuk mewujudkan wirausaha baru mandiri dengan usaha berbasis IPTEKS. Target khusus program tersebut untuk menghasilkan lima mahasiswa menjadi wirausaha baru yang mandiri. Metode pelaksanaan yang dilakukan untuk merealisasikan kegiatan, digunakan pelatihan/pembekalan untuk mmberikan pemahaman lanjutan tentang kewirausahaan, manajemen usaha, manajemen pemasaran, dan juga kepemimpinan; praktikum dengan kegiatannya praktek membuat produk sesuai dengan niat masing-masing peserta; pendampingan, dan magang. Hasil yang dicapai adalah terfasilitasinya semua kegiatan dan menghasilkan lima tenant sebagai wirausaha baru mandiri yang siap beroperasi dengan lima kluster usaha. Program ini untuk merubah perilaku mahasiswa menjadi seorang wirausaha mandiri tidak cukup hanya intervensi dari pihak luar tetapi harus juga ada kemauan dan motivasi dari mahasiswa itu sendiri.
\end{abstract}

Katakunci: Program Pengembangan Kewirausahaan, mahasiswa, wirausaha mandiri.

\section{Abstract}

The trend every year of higher education graduates is relatively low interest in entrepreneurship. This can be seen from the increasing number of graduates applying to become Civil Servants. One solution to anticipate this is to train students to become independent entrepreneur beginners. Entrepreneurship Development Program is one of the community service activities specifically for students. The Entrepreneurship Development Program (PPK) is one of the community service activities specifically for students funded by the Ministry of Technology Research and Higher Education in 2019. 
The purpose of this activity is to realize new independent entrepreneurs with Science and Technology and art-based businesses. Specific target of this program is to produce at least five students into independent new entrepreneurs. The method of implementation carried out to realize the activities, used training/briefing to provide an advanced understanding of entrepreneurship, business management, marketing management, and leadership; practicum with its activities the practice of making products in accordance with each participant's interest; assistance, and internships. The results achieved were the facilitation of all activities and produced five tenants as new independent entrepreneurs who were ready to operate with five business clusters. The program to change student behavior into an independent entrepreneur is not enough to just intervene from outside parties but there must also be a will and motivation from the students themselves.

Keywords: Entrepreneurship Development Program, students, independent entrepreneur

\section{PENDAHULUAN}

Kewirausahaan masih sangat menarik diangkat karena dapat memberikan kontribusi pada sektor ekonomi dan sosial. Upaya pemerintah meningkatkan kualitas sumberdaya manusia baik lulusan sekolah menengah maupun pendidikan tinggi untuk menjadi seorang wirausaha terus ditingkatkan. Program yang telah dilaksanakan di lembaga pendidikan antara lain tersedianya unit produksi dan teaching factory di SMK dan kegiatan magang di industri (Soputan, 2017) dan Program Mahasiswa Wirausaha di Perguruan Tinggi. Tujuannya untuk mendorong para siswa dan mahasiswa menjadi wirausaha muda setelah mereka lulus dari sekolah dan perguruan tinggi. Fenomena ini terjadi juga di Malaysia (Wei-Loon Koe, et al, 2012), (Gabriel Chu,2017).

Ratio wirausaha di Indonesia masih sangat sedikit $(3,1 \%)$ dibandingkan dengan Malaysia (5\%), Singapura (7\%), China (10\%), Jepang (11\%), dan Amerika (12\%). Tingkat pengangguran terbuka paling banyak adalah lulusan SMK (7,58\%) dan Pendidikaan Tinggi (5,92\%). (BPS, 2018).

Kondisi Kewirausahaan di Fakultas Ekonomi sejak Tahun 2011 sampai 2017 terdapat perkembangan meningkat jika dilihat dari usuluan proposal untuk mendapatkan dana Program Mahasiswa Wirausaha (PMW).

Tahun 2011 berjumlah 20 pengusul, yang didanai 10 proposal dengan total dana $\mathrm{Rp}$ 40.000.000. Tahun 2012, 25 pengusul, yang dibiayai 10 proposal dengan dana $\mathrm{Rp}$ 40.000.000. Tahun 2013 hanya 10 proposal yang diusulkan dan yang diterima 5 proposal dengan dana $\mathrm{Rp}$ 15.000.000. Tahun 2014 jumlah pengusul 25 dan yang didanai 20 proposal dengan dana Rp 80.000.000. Pada tahun 2015 animo pengusul makin meningkat yaitu 45 proposal yang masuk dan yang didanai 38 proposal dengan jumlah dana $\mathrm{Rp}$ 152.000.000. Tahun 2016 jumlah proposal yang diusulkan sebanyak 50 dan yang diterima 40 dengan jumlah dana sebesar 160.000.000. Tahun 2017 
jumlah pengusul sebanyak 50 orang dan yang diterima 30 mahasiswa.

Keberlanjutan usaha tidak terpantau oleh dosen pendamping atau pimpinan program studi karena mereka yang mendapatkan PMW sudah lulus dan sebagian lagi berhenti. Hal-hal yang menyebabkan sebagian mahasiswa berhenti, karena berkonsentrasi untuk penyelesaian studi. Mahasiswa yang mendapatkan pendanaan tersebut rata-rata berada pada semester 6 ke atas. Dana yang diberikan hanya sebagai tambahan modal kerja.

Permasalahan yang tergambar sampai tahun 2018 adalah keberlangsungan usaha yang telah mendapatkan dana PMW tidak terpantau. Selain itu minat dari mahasiswa yang lain untuk mengajukan proposal PMW masih kurang, padahal peluangnya besar. Hal ini disebabkan karena masih banyak mahasiswa yang belum tertarik dan belum mampu menyusun proposal bisnis.

Permasalahan tersebut dapat diatasi melalui Program Pengembangan Kewirausahaan (PPK). Tujuan penyelenggaraan PPK adalah mewujudkan wirausaha mandiri dengan usaha berbasis IPTEKS. Selain itu, pelaksanaan PPK untuk mengetahui metode dalam merintis usaha baru (Metode Start-up Business). Motivasi juga menjadi perhatian utama dalam proses pembekalan. Motivasi akan menumbuhkan rasa percaya diri bahwa dirinya mampu menciptakan usaha sendiri dan membuka lapangan kerja bagi orang lain. Permasalahan dapat dirinci sebagai berikut: (1) Para mahasiswa masih kurang berminat untuk terlibat dalam kegiatan kewirausahan, padahal banyak peluang yang ditawarkan baik internal di Universitas maupun di Kementerian Ristekdikti. Tantangan bagi Fakultas Ekonomi jika mahasiswa yang tertarik dalam berwirausaha relatif sedikit maka mahasiswa akan dianggap hanya mengetahui teori saja. Mahasiswa sudah banyak mendapatkan teori tentang bisnis tetapi tidak dipraktekkan. (2) Masalah yang lain mahasiswa yang sudah mengusulkan proposal ke tingkat Universitas masih ada yang tidak lolos karena rencana bisnisnya tidak tersusun dengan benar. (3) Jumlah mahasiswa yang didanai untuk kegiatan PMW yang tidak jalan usahanya relatif banyak. (4) Masih ada mahasiswa yang merasa malu jika dia harus berjualan.

Tujuan kegiatan Program Pengembangan Kewirausahaan adalah untuk mewujudkan wirausaha mandiri dengan usaha berbasis IPTEKS

\section{METODE PELAKSANAAN}

\subsection{Pola Rekrutmen}

Kegiatan rekrutmen dimulai dengan memberikan sosialisasi kepada mahasiswa melalui poster. Mahasiswa dan alumni diberikan kesempatan untuk mendaftar sebagai calon peserta Program Pengembangan Kewirausahaan. Selain ditujukan kepada mahasiswa pada umumnya, tim rekrutmen mengutamakan mahasiswa yang sudah pernah mengusulkan proposal Program Mahasiswa Wirausaha (PMW) maupun para mahasiswa yang sudah punya usaha sendiri. 
Secara rinci prosedur rekrutmen calon tenant adalah sebagai berikut:

1. Tim pelaksana mensosialisasikan kepada mahasiswa yang berminat untuk mengikuti seleksi

2. Calon tenan mendaftar ke sekretariat PPK dengan mengisi formulir yang disiapkan oleh tim pelaksana

3. Tim mengadakan penjaringan melalui seleksi (dalam bentuk assesment) dan wawancara.

4. Tim memilih 20 orang tenant untuk dibina pada program PPK.

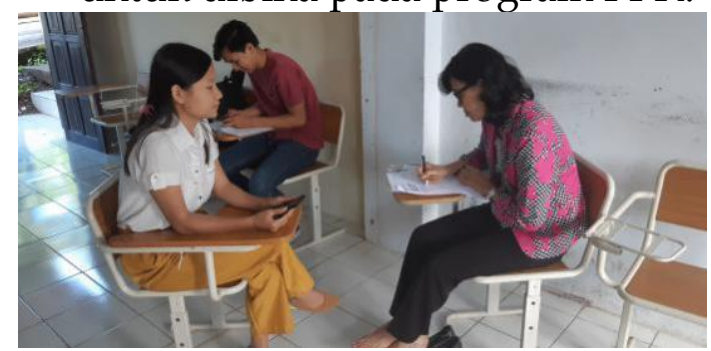

Gambar 1. Proses Wawancara

Metode yang diterapkan pada pemecahan masalah pertama adalah pelatihan/pembekalan. Metode ini digunakan untuk memberikan pelatihan atau pembekalan kepada mahasiswa tenant dengan tahapan sebagai berikut:

a. Mahasiswa diberikan pelatihan/ pembekalan dengan materi berupa motivasi untuk berwirausaha. Dalam pelatihan tersebut diberikan juga testimoni alumni atau mahasiswa yang sudah menjadi wirausaha mandiri sukses dalam aktivitas di masyarakat. Tujuannya memberikan motivasi kepada mahasiswa supaya mereka tergerak untuk berwirausaha.

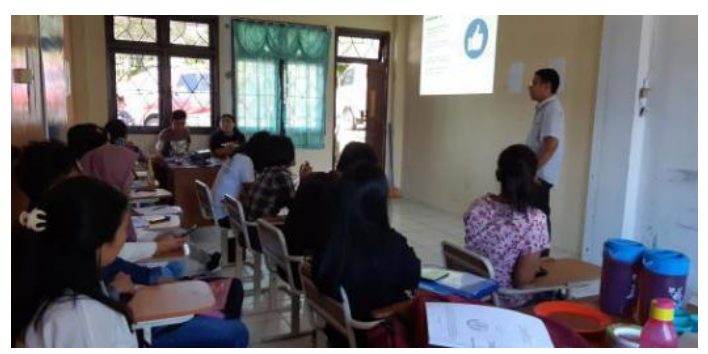

Gambar 2. Pelatihan awal

b. Memutarkan video Success story, supaya mahasiswa dapat melihat dan dapat meningkatkan mental wirausaha yang pantang menyerah. Sekali jatuh, seribu kali bangkit dan tidak henti-henti untuk berinovasi dalam mencapai kesuksesan.

c. Setelah selesai pemberian materi mahasiwa diberikan angket untuk melihat feedback terhadap materi yang diberikan

Pemecahan masalah kedua, metode yang digunakan adalah pelatihan dan pendampingan. Pelatihan digunakan untuk materi tentang cara menyusun rencana usaha (business plan) dan pendampingan pada saat tenant menyusun rencana usaha sesuai jenis usaha yang telah dipilih. Bimbingan teknis berupa produksi usaha kuliner dan kerajinan.

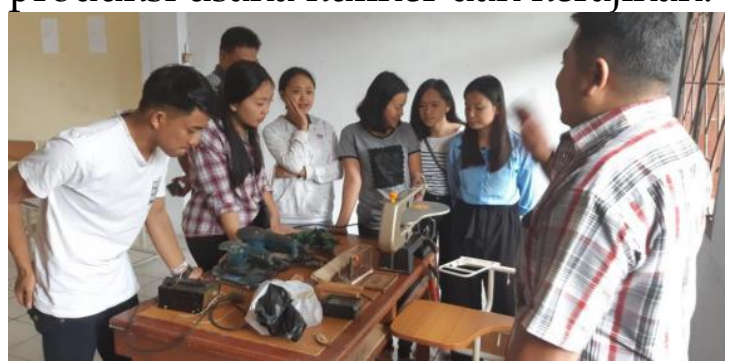

Gambar 3. Bimtek Kerajinan Limbah

Kayu

Pemecahan masalah ketiga menggunakan metode pemagangan di UKM yang cukup berhasil (IKM Mitra) baik berbasis usaha rumahan 
maupun UKM yang sudah maju. Magang selain meningkatkan ketrampilan para tenant juga untuk meningkatkan kepercayaan diri bagi tenant dalam menjalankan usaha mereka. Magang juga dapat memberikan motivasi dan pembelajaran teristimewa tentang mental atau jiwa seorang wirausaha harus siap menanggung resiko dan tidak mudah menyerah pada keadaan.

\section{HASIL DAN PEMBAHASAN}

\subsection{Peningkatan Pengetahuan dan Ketrampilan Kewirausahaan.}

Kegiatan PPK dilaksanakan bulan April sampai Oktober 2019. Mahasiswa peserta terdiri dari perwakilan program studi yang ada di Fakultas Ekonomi yaitu Program studi Manajemen, Akuntansi, Pendidikan Ekonomi, Manajemen Pemasaran (D3) dan Ilmu Ekonomi. Setelah proses pelatihan awal dan pelatihan kewirausahaan mahasiswa tenant dapat meningkat pengetahuan mereka baik tentang teori kewirausahaan maupun praktek kewirausahaan. Praktek kewirausahaan para tenant diberikan pelatihan pembuatan beberapa macam usaha kuliner. Setelah kegiatan pelatihan berlangsung baik teori maupun praktek selama lima bulan terlihat ada peningkatan jiwa wirausaha para peserta. Hal ini dapat dilihat dari motivasi peserta untuk memproduksi beberapa macam produk kuliner, produk multi fungsi, produk kerajinan, dan lain-lain. Disamping memproduksi para tenant menjual sendiri di lingkungan kampus Fakultas Ekonomi dan sekitarnya.
Pelatihan dari dosen-dosen kewirausahaan dan Teknologi Informasi, juga dan bimbingan teknis diberikan oleh pelaku usaha bidang kuliner dan kerajinan berbahan baku limbah kayu. Hasil dari pelatihan dan bimbinga teknis, para mahasiswa tenant termotivasi untuk melakukan usaha di bidang kuliner dan kerajinan sesuai minat masing-masing.

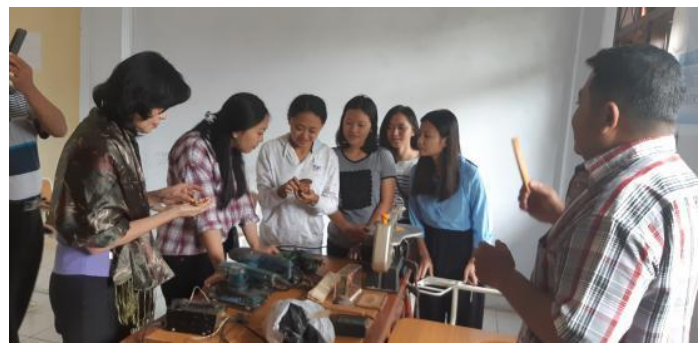

Gambar 4. Bimtek Kerajinan

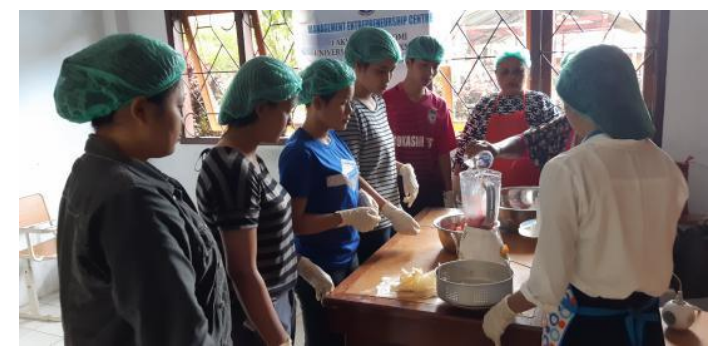

Gambar 5. Bimtek Kuliner

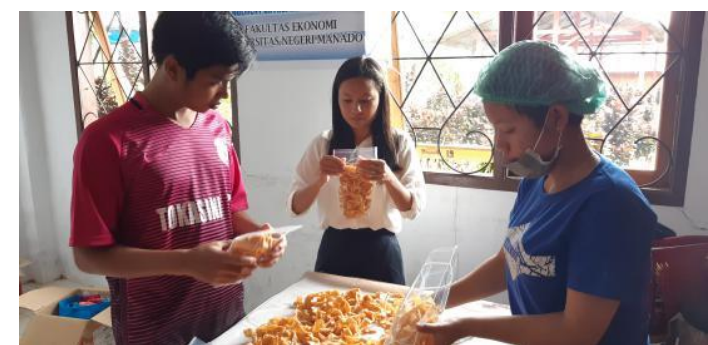

Gambar 6. Hasil Produksi Sedang

Dikemas

\subsection{Terciptanya Wirausaha Muda Mandiri}

Dampak positif Program Pengembangan Kewirausahaan di Fakultas Ekonomi, antara lain motivasi mahasiswa untuk berwirausaha mulai nampak. 
Berdasarkan evaluasi selama proses kegiatan tim pelaksana menetapkan 5 tenant sebagai wirausaha mandiri. Kelima tenant tersebut memiliki kluster usaha kuliner, kerajinan berbasis limbah kayu, kerajinan gerabah, produk multi fungsi, dan jasa mengedit naskah dan scan dokument serta print out dokumen. Usaha dari kelima tenant terdapat satu orang tenant yang sudah berkembang usahanya yaitu produk multi fungsi berupa buket bunga, topi almamater, selempang, dan buket balon.

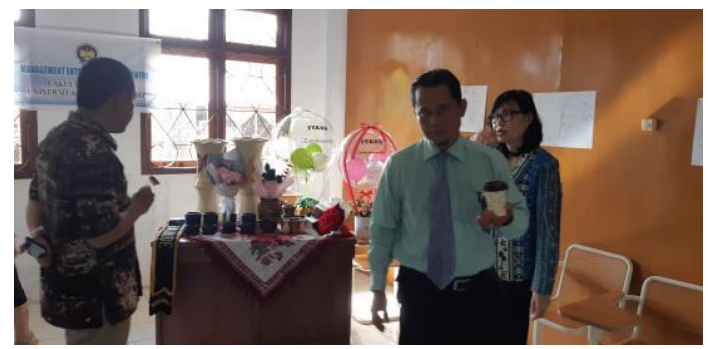

Gambar 7. Produk Kerajinan dan Multi Fungsi

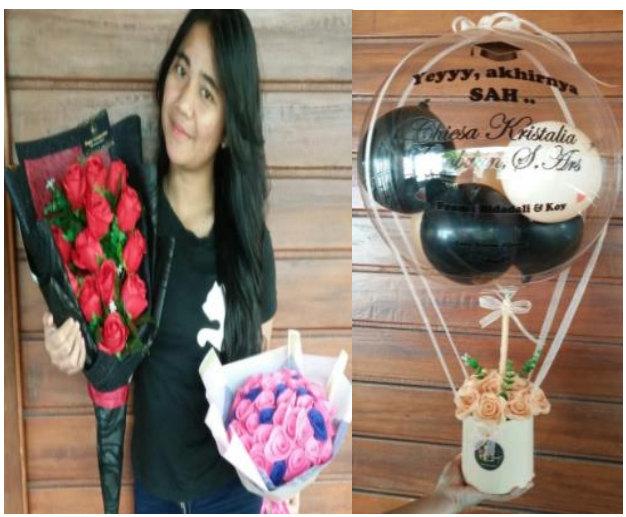

Gambar 8. Salah Satu Tenant Yang Berhasil Dengan Produk Multi Fungsi

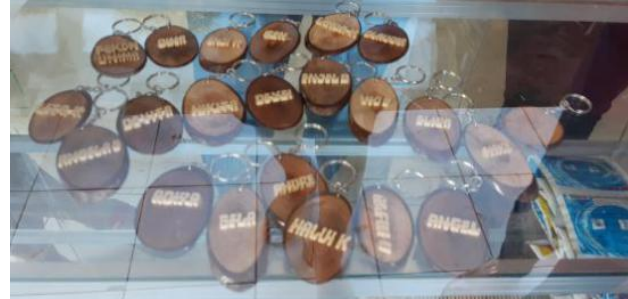

Gambar 9. Produk Kerajinan

Gantungan Kunci Berbasis Limbah Kayu
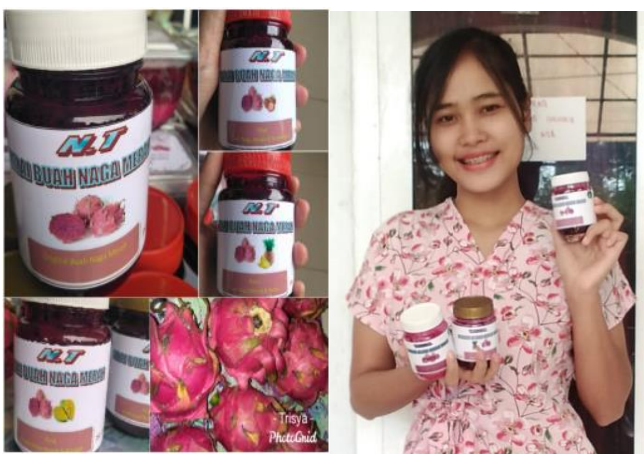

Gambar 10. Tenant Dengan Produk Selai Buah Naga

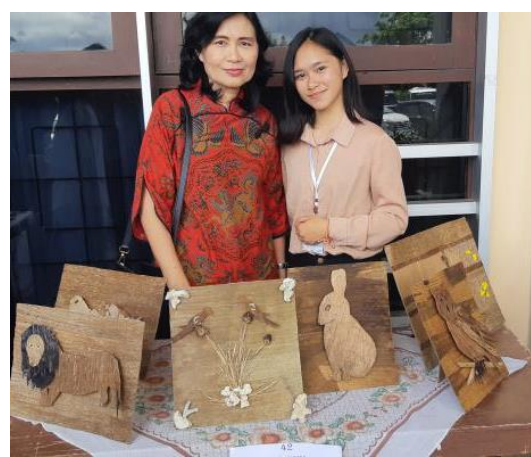

Gambar 11. Tenant Dengan Produk Kerajinan Pelepah Pisang 


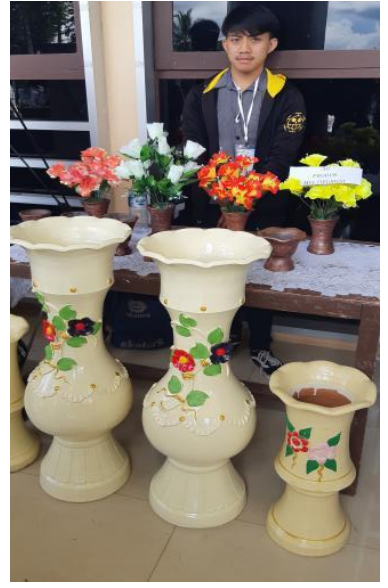

Gambar 12. Tenant Dengan Produk Kerajinan Gerabah

\subsection{Perubahan Perilaku Mahasiswa Tenant}

Upaya merubah perilaku seseorang tidaklah mudah seperti membalikkan telapak tangan. Dibutuhkan proses yang panjang dan berkesinambungan. Dampak kegiatan Program

Pengembangan Kewirausahaan ini terlihat adanya perubahan perilaku meskipun sedikit. Mahasiswa yang dibina sebanyak 20 orang, hanya ada 5 orang yang menunjukkan adanya perubahan perilaku wirausaha. Lima mahasiswa tersebut terdapat satu mahasiswa yang sudah eksis dengan produk multi fungsinya yang dapat dikatakan sukses. Jangkauan pemasarannya sudah sampai ke kampus-kampus yang ada di kota Manado. Malahan sudah menggunakan tenaga kerja sesama mahasiswa untuk membantu di bidang produksi dan distribusi produk. Produk yang dihasilkan berupa buket bunga tangan, selempang, topi almamater dan buket balon. Data kelima tenant tersebut dapat dilihat pada tabel berikut ini:
Tabel 1. Wirausaha Baru Program Pengembangan Kewirausahaan Tahun 2019

No. Nama /Usaha Omset/bln

1 Ully/buket bunga/10 - 15 juta

2 Nyoman/Selei bh Naga 3,5 juta

3 Renaldy/Kerajinan/4 juta

4 Friska/snack Tuna/3 juta

5 Citra/Salad buah/3 juta

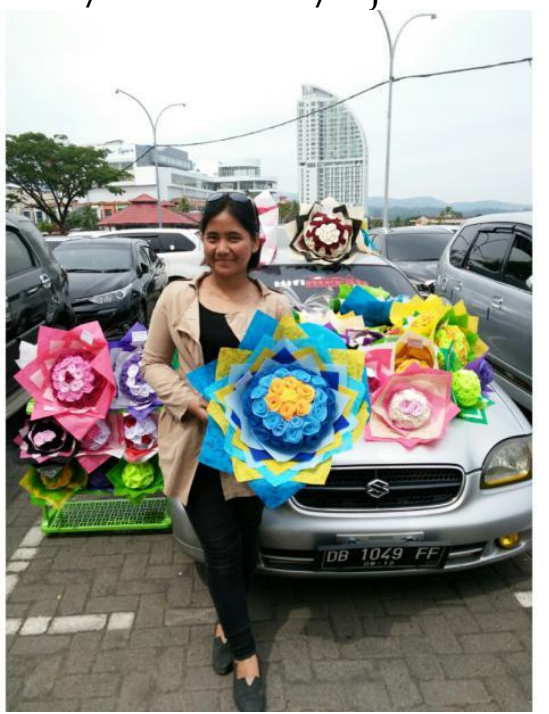

Gambar 13. Produk Buket Bunga yang Dijual Kepada Lulusan dan Wisudawan

Perubahan

perilaku ditunjukkan melalui pemahaman pengetahuan kewirausahaan dan sikap yang mau bertindak, dan akhirnya menghasilkan produk yang dapat dijual dan menghasilkan pendapatan meskipun masih dalam skala kecil. Motivasi untuk memproduksi sesuatu produk yang sesuai dengan ide bisnis mereka dapat direalisasikan dan dapat dipasarkan di lingkungan mahasiswa dan dosen.

Hasil pemantauan tim pelaksana PPK mulai rekrutmen sampai proses produksi dan pemasaran 30 persen peserta telah menunjukkan perilaku berwirausaha. Mereka bukan saja memiliki ide bisnis tetapi sudah 
melakukan dan merealisasikan ide tersebut. Pendidikan kewirausahaan yang secara sengaja diberikan kepada mahasiswa sebagai upaya untuk membentuk perilaku wirausaha dari peserta PPK.

Perubahan perilaku mahasiswa tenant dapat dilihat antara lain: 1) kepercayaan diri meningkat; 2) pola pikir berubah; 3) kerja keras; 4) berani mengambil resiko; 5) adanya kreatifitas dalam memodifikasi produk.

Meskipun hasil yang dicapai masih dalam skala kecil tetapi perilaku sebelum mengikuti Program Pengembangan Kewirausahaan dan sesudah mengikuti terdapat perbedaan sikap dan perilaku. Sebelum mengikuti kegiatan ini para mahasiswa masih merasa malu melakukan usaha, karena belum percaya diri, belum menunjukkan keberanian dalam bertindak, belum berani tampil beda dengan teman-teman mahasiswa lainnya. Setelah mereka sudah merasakan manfaat dari kegiatan ini maka sudah ada tenant yang mulai mengajak mahasiswa didorong dan dikembangkan oleh pihak eksternal maka mereka tidak akan mampu berusaha sendiri. Hal ini wajar karena mereka masih dalam proses pendidikan, setiap hari harus mengikuti perkuliahan sesuai jadwal yang ditetapkan. Program Pengembangan Kewirausahaan merupakan program intervensi kepada mahasiswa untuk dibina menjadi seorang wirausaha mandiri. Dampak positif dari kegiatan ini nampak pada sikap dan perilaku tenant jika terdapat waktu luang selesai mengikuti perkuliahan mereka memanfaatkan dengan memasarkan produk-produk hasil karya sendiri kepada dosen dan teman-teman mahasiswa.

Hasil kegiatan ini sejalan dengan hasil penelitian Gabriel Chu, \& Samuel Ang (2017) bahwa institusi pendidikan dapat membantu mahasiswanya untuk mengembangkan pola pikir dan kepercayaan diri serta keahlian dengan berbasis pelatihan kewirausahaan dan inovasi. Raymond Kao, et.al (2010) dalam penelitiannya menemukan bahwa tujuan dari program pelatihan dan pengembangan untuk mempromosikan partisipasi perempuan wirausaha di China. Sejalan dengan Theory Planned Behavior (Ajzen, I, 1991) terdapat tiga aspek yaitu: attitude, subjective norm, and perceive behavioral control. Artinya niat untuk melakukan perilaku dari berbagai jenis dapat diprediksi dengan akurasi tinggi dari sikap terhadap perilaku, norma subyektif, dan kontrol perilaku yang dirasakan; dan niat ini, bersama dengan persepsi kontrol perilaku, menjelaskan perbedaan yang signifikan dalam perilaku aktual.

Yuha Yang, et.al (2018) mengutip pendapat Ajzen, tiga prediktor formatif dari sikap terhadap perilaku adalah: (a) sejauh mana seseorang memiliki penilaian positif atau negatif dari perilaku yang diberikan; (b) norma subyektif adalah harapan sosial seseorang atau tekanan yang dirasakan untuk melakukan perilaku yang dipertanyakan, dan (c) kontrol perilaku yang dirasakan adalah kompetensi yang dirasakan seseorang dalam melakukan perilaku 
berdasarkan pengalaman masa lalu atau halangan yang diantisipasi.

\section{KESIMPULAN}

Program

Pengembangan

Kewira- usahaan merupakan salah satu kegiatan Pengabdian kepada Masyarakat untuk meningkatkan kompetensi kewirausahaan bagi mahasiswa. Hasil kegiatan tersebut dapat disimpulkan sebagai berikut:

Terjadi perubahan pola pikir dan perilaku wirausaha bagi mahasiswa tenant. Selanjutnya terjadi peningkatan motivasi berwirausaha bagi mahasiswa tenant; menghasilkan lima wirausaha mandiri yang siap melakukan usaha meskipun dalam skala kecil; serta memberikan dampak positif kepada mahasiswa lain yang belum tergabung dalam kelompok Program Pengembangan

Kewirausahaan.

\section{UCAPAN TERIMA KASIH}

Penghargaan dan ucapan terima kasih penulis sampaikan kepada Direktur Riset dan Pengabdian Masyarakat Prof. Dr. Ocky Karna Radjasa, yang telah membiayai Program Pengembangan Kewirausa- haan (PPK) di Fakultas Ekonomi Universitas Negeri Manado. Terima kasih juga kepada Rektor Universitas Negeri Manado, Prof. Dr. Julyeta P.A. Runtuwene, MSi bersama Ketua LPPM Prof. Dr. Revolson A. Mege, MS yang telah memberikan dana pendamping dalam kegiatan ini.

\section{DAFTAR PUSTAKA}

Ajzen, I. (1991). The theory of planned behavior. Organizational Behavior and Human Decision Processes, 50, 179-211. https://doi.org/cc3

Badan Pusat Statistik. 2018

Gabriel Chu and Samuel Ang. 2017. Entrepreneurial Mindset and Motivations of Youth. $7^{\text {th }}$ Annual International Conference on Innovation and Entrepreneurship, (IE2017), ISSN 2251- 2039, doi:10.5176/2251-2039_IE17.8. https://doi.org/10.2224/sbp 6832

Sumual H, \& Soputan G.J. 2018, Entrepreneurship Education through Industrial Internship for Technical and Vocational Students. ICIEVE 2017. IOP Conf. Series: Materials Science and Engineering $306 \quad$ (2018) 012053 doi:10.1088/1757-899X/306/1/0 12053

Wei-Loon Koe, et.al. 2012. Determinants of

Entrepreneur- ial Intention Among Millennial Generation. Procedia Social and Behavioral Sciences 40 (2012) 197 - 208

Yuha Yang, Jin Nam Choi, And Kyungmook Lee. 2018. Theory of Planned Behavior and Different Forms of Organizational Change Behavior. Social Behavior and Personality, 46(10),1657-1672. 